Nat. Hazards Earth Syst. Sci., 18, 3085-3087, 2018

https://doi.org/10.5194/nhess-18-3085-2018

(C) Author(s) 2018. This work is distributed under

the Creative Commons Attribution 4.0 License.

\title{
Preface: The use of remotely piloted aircraft systems (RPAS) in monitoring applications and management of natural hazards
}

\author{
Daniele Giordan $^{1}$, Yuichi S. Hayakawa ${ }^{2, a}$, Francesco $\mathrm{Nex}^{3}$, and Paolo Tarolli ${ }^{4}$ \\ ${ }^{1}$ Istituto di Ricerca per la Protezione Idrogeologica, Consiglio Nazionale delle Ricerche, Turin, Italy \\ ${ }^{2}$ Center for Spatial Information Science, The University of Tokyo, Tokyo, Japan \\ ${ }^{3}$ University of Twente, Faculty of Geo-Information Science and Earth Observation (ITC), Twente, the Netherlands \\ ${ }^{4}$ Department of Land, Environment, Agriculture and Forestry, University of Padova, Padua, Italy \\ ${ }^{a}$ now at: Faculty of Environmental Earth Science, Hokkaido University, Hokkaido, Japan
}

Correspondence: Daniele Giordan (daniele.giordan@irpi.cnr.it)

Published: 19 November 2018

The use of remotely piloted aerial systems (RPAS) has shown a strong improvement in last years. Starting from typical applications like archaeology (Koutsoudisa et al., 2014; Mesas-Carrascosa et al., 2016; Lazzari and Gioia, 2017), today these systems are nowadays used in different domains including precision farming (Salamì et al., 2014), architecture (Roca et al., 2013; Dominici et al., 2017), study of natural phenomena (Gomez and Purdie, 2016; Giordan et al., 2017) and their effects (Giordan et al., 2018b), and study of human impact on Earth (Xiang et al., 2018). RPAS equipped with RGB photo cameras and the development of more efficient photogrammetric techniques (Westoby et al., 2012) had simplified the fast acquisition of a sequence of images and they had multiplied the possible uses of these systems that are now able to reliably and easily produce a digital surface model and an orthophoto (Nex and Remondino, 2014). These approaches can be very useful for the study of natural hazards, for which an on-demand system able to acquire high-resolution image datasets in a limited lapse of time can be very useful. The availability of a detailed representation of the hazardous natural process or its effects can be an important support for (i) comprehension of the evolution of the natural process that could create a hazardous condition, (ii) timely monitoring during emergencies, (iii) residual risk assessment, and (iv) first estimation of occurred damages. In this special issue, we selected and published different contributions presented in a thematic session of the European Geosciences Union General Assembly of 2016 and 2017. These sessions were dedicated to the use of RPAS in monitoring applications and management of natural hazards. The objective of the presented special issue is to provide the sci- entific community with a wide description of possible uses of RPAS for the study of active natural processes and their impacts on environment and society. Giordan et al. (2018a) published a review of the possible use of RPAS for the characterization and management of landslides, floods, wildfires, volcanic activity, and earthquakes. Glacier evolution and related hazard assessment has been described by Fugazza et al. (2018), who presented the use of RPAS for the study of one of the most important glaciers in Italy, the Forni Glacier. The theme of landslides is considered by many authors with different approaches. Török et al. (2018) and Saroglou et al. (2018) focused their attention on rockfalls and their possible effects. Rock slope stability has also been considered by Salvini et al. (2018), to support the safety of rocky mining activities. Landslide identification and mapping is described by Fiorucci et al. (2018), who considered ultra-highresolution images for the definition of landslide limits and their evolution. Peppa et al. (2017) presented a methodology for the definition of the landslide evolution too: in particular, their paper proposes the use of a multi-temporal dataset and a cross-correlation approach for the detection and measurement of morphological changes due to landslide activity. The geomorphological description and the potential risk of debris avalanche (i.e. a particular type of landslide) deposits related to the collapse of a volcano sector is presented by Hayakawa et al. (2018). Hayakawa obtained a high-resolution DTM using RPAS that was fundamental for the geomorphological description of the studied area. A similar approach was used by Chang et al. (2018), who focused their paper on landslides and used RPAS for the geomorphological investigation. In this paper, authors paid particular attention to the 
triggering role of active faults. The theme of active tectonic processes is also considered by Deffontaines et al. (2018), who describe the characterization of active faults in Taiwan, with specific regard to the earthquakes that occurred on 21 September 1999 and 26 December 2006 using different datasets: GPS monitoring data, PS-InSAR time series, and mean- and high-resolution digital surface model (DSM) derived from old aerial photos and RPAS. The use of RPAS in post-earthquake scenarios is described by Cannioto et al. (2017), who presented how RPAS could help during search and rescue activities with the recognition of the shortest survey path in highly damaged areas. The use of RPAS for emergency investigation is described by Huang et al. (2017), who describe a methodological approach for the use of RPAS for emergency investigations of a single geo-hazard mission.

Another relevant topic is the effect of surficial water flow and related hazards. An automatic gully detection application is proposed by Feurer et al. (2018), who also suggest the fruitful use of kites for the acquisition of aerial images. Benassai et al. (2017) presented the study of rip current effects and hydrodynamic simulation results based on the use of RPAS, while the use of these platforms for the study of disastrous flood effects is presented by Izumida et al. (2017). Duo et al. (2018) proposed a methodology for the rapid mapping of impacts by extreme storm events on coasts based on the use of RPAS.

The collection of papers proposed to the NHESS readers provides a critical description of the state of the art in the use of RPAS for different scenarios. In particular, the sequence of papers can be considered an exhaustive representation of the state of the art of the methodologies and approaches applied to the study and management of natural hazards.

\section{References}

Benassai, G., Aucelli, P., Budillon, G., De Stefano, M., Di Luccio, D., Di Paola, G., Montella, R., Mucerino, L., Sica, M., and Pennetta, M.: Rip current evidence by hydrodynamic simulations, bathymetric surveys and UAV observation, Nat. Hazards Earth Syst. Sci., 17, 1493-1503, https://doi.org/10.5194/nhess17-1493-2017, 2017.

Cannioto, M., D'Alessandro, A., Lo Bosco, G., Scudero, S., and Vitale, G.: Brief communication: Vehicle routing problem and UAV application in the post-earthquake scenario, Nat. Hazards Earth Syst. Sci., 17, 1939-1946, https://doi.org/10.5194/nhess17-1939-2017, 2017.

Chang, K.-J., Chan, Y.-C., Chen, R.-F., and Hsieh, Y.-C.: Geomorphological evolution of landslides near an active normal fault in northern Taiwan, as revealed by lidar and unmanned aircraft system data, Nat. Hazards Earth Syst. Sci., 18, 709-727, https://doi.org/10.5194/nhess-18-709-2018, 2018.

Deffontaines, B., Chang, K. J., Champenois, J., Lin, K. C., Lee, C. T., Chen, R. F., Hu, J. C., and Fruneau, B.: Active tectonics of the onshore Hengchun Fault using UAS DTM combined with ALOS PS-InSAR time series (Southern Taiwan), Nat. Hazards
Earth Syst. Sci., 18, 829-845, https://doi.org/10.5194/nhess-18829-2018, 2018.

Dominici, D., Alicandro, M., and Massimi, V.: UAV photogrammetry in the post-earthquake scenario: case studies in L'Aquila, Geomat. Nat. Hazards Risk, 8, 87-103, 2017.

Duo, E., Trembanis, A. C., Dohner, S., Grottoli, E., and Ciavola, P.: Local-scale post-event assessments with GPS and UAV-based quick-response surveys: a pilot case from the Emilia-Romagna (Italy) coast, Nat. Hazards Earth Syst. Sci., 18, 2969-2989, https://doi.org/10.5194/nhess-18-2969-2018, 2018

Feurer, D., Planchon, O., El Maaoui, M. A., Ben Slimane, A., Boussema, M. R., Pierrot-Deseilligny, M., and Raclot, D.: Using kites for 3-D mapping of gullies at decimetre-resolution over several square kilometres: a case study on the Kamech catchment, Tunisia, Nat. Hazards Earth Syst. Sci., 18, 1567-1582, https://doi.org/10.5194/nhess-18-1567-2018, 2018.

Fiorucci, F., Giordan, D., Santangelo, M., Dutto, F., Rossi, M., and Guzzetti, F.: Criteria for the optimal selection of remote sensing optical images to map event landslides, Nat. Hazards Earth Syst. Sci., 18, 405-417, https://doi.org/10.5194/nhess-18-4052018, 2018.

Fugazza, D., Scaioni, M., Corti, M., D’Agata, C., Azzoni, R. S., Cernuschi, M., Smiraglia, C., and Diolaiuti, G. A.: Combination of UAV and terrestrial photogrammetry to assess rapid glacier evolution and map glacier hazards, Nat. Hazards Earth Syst. Sci., 18, 1055-1071, https://doi.org/10.5194/nhess18-1055-2018, 2018.

Giordan, D., Manconi, A., Remondino, F., and Nex, F.: Use of unmanned aerial vehicles in monitoring application and management of natural hazards, Geomat. Nat. Hazard Risk, 8, 1-4, 2017

Giordan, D., Hayakawa, Y., Nex, F., Remondino, F., and Tarolli, P.: Review article: the use of remotely piloted aircraft systems (RPASs) for natural hazards monitoring and management, Nat. Hazards Earth Syst. Sci., 18, 1079-1096, https://doi.org/10.5194/nhess-18-1079-2018, 2018 a.

Giordan, D., Notti, D., Villa, A., Zucca, F., Calò, F., Pepe, A., Dutto, F., Pari, P., Baldo, M., and Allasia, P.: Low cost, multiscale and multi-sensor application for flooded area mapping, Nat. Hazards Earth Syst. Sci., 18, 1493-1516, https://doi.org/10.5194/nhess18-1493-2018, 2018b.

Gomez, C. and Purdie, H.: UAV- based Photogrammetry and Geocomputing for Hazards and Disaster Risk Monitoring - A Review, Geoenviron. Disast., 3, 1-11, 2016.

Hayakawa, Y. S., Yoshida, H., Obanawa, H., Naruhashi, R., Okumura, K., Zaiki, M., and Kontani, R.: Characteristics of debris avalanche deposits inferred from source volume estimate and hummock morphology around Mt. Erciyes, central Turkey, Nat. Hazards Earth Syst. Sci., 18, 429-444, https://doi.org/10.5194/nhess-18-429-2018, 2018.

Huang, H., Long, J., Yi, W., Yi, Q., Zhang, G., and Lei, B.: A method for using unmanned aerial vehicles for emergency investigation of single geo-hazards and sample applications of this method, Nat. Hazards Earth Syst. Sci., 17, 1961-1979, https://doi.org/10.5194/nhess-17-1961-2017, 2017.

Izumida, A., Uchiyama, S., and Sugai, T.: Application of UAV-SfM photogrammetry and aerial lidar to a disastrous flood: repeated topographic measurement of a newly formed crevasse splay of the Kinu River, central Japan, Nat. Hazards Earth Syst. Sci., 17, 1505-1519, https://doi.org/10.5194/nhess-17-1505-2017, 2017. 
Koutsoudisa, A., Vidmarb, B., Ioannakisa, G., Arnaoutogloua, F., Pavlidis, V., and Chamzasc, C.: Multi-image 3D reconstruction data evaluation, J. Cult. Herit., 15, 73-79, 2014.

Lazzari, M. and Gioia, D.: UAV images and high-resolution DEMs for geomorphological analysis and hazard evaluation: the case of the Uggiano archaeological site (Ferrandina, southern Italy), Geomat. Nat. Hazards Risk, 8, 104-119, 2017.

Mesas-Carrascosa, F.-J., Notario García, M. D., Meroño de Larriva, J. E., and García-Ferrer, A.: An Analysis of the Influence of Flight Parameters in the Generation of Unmanned Aerial Vehicle (UAV) Orthomosaicks to Survey Archaeological Areas, Sensors, 16, 1838, https://doi.org/10.3390/s16111838, 2016.

Nex, F. and Remondino, F.: UAV for 3D mapping applications: a review, Appl. Geomat., 6, 1-15, 2014.

Peppa, M. V., Mills, J. P., Moore, P., Miller, P. E., and Chambers, J. E.: Brief communication: Landslide motion from cross correlation of UAV-derived morphological attributes, Nat. Hazards Earth Syst. Sci., 17, 2143-2150, https://doi.org/10.5194/nhess17-2143-2017, 2017.

Roca, D., Lagüela, S., Díaz-Vilariño, L., Armesto, J., and Arias, P.: Low-cost aerial unit for outdoor inspection of building façades, Automat. Construct., 36, 128-135, 2013.

Salamí, E., Barrado, C., and Pastor, E.: UAV Flight Experiments Applied to the Remote Sensing of Vegetated Areas, Remote Sens., 6, 11051-11081, 2014.
Salvini, R., Mastrorocco, G., Esposito, G., Di Bartolo, S., Coggan, J., and Vanneschi, C.: Use of a remotely piloted aircraft system for hazard assessment in a rocky mining area (Lucca, Italy), Nat. Hazards Earth Syst. Sci., 18, 287-302, https://doi.org/10.5194/nhess-18-287-2018, 2018.

Saroglou, C., Asteriou, P., Zekkos, D., Tsiambaos, G., Clark, M., and Manousakis, J.: UAV-enabled reconnaissance and trajectory modeling of a co-seismic rockfall in Lefkada, Nat. Hazards Earth Syst. Sci., 18, 321-333, https://doi.org/10.5194/nhess-18-3212018, 2018.

Török, Á., Barsi, Á., Bögöly, G., Lovas, T., Somogyi, Á., and Görög, P.: Slope stability and rockfall assessment of volcanic tuffs using RPAS with 2-D FEM slope modelling, Nat. Hazards Earth Syst. Sci., 18, 583-597, https://doi.org/10.5194/nhess-18583-2018, 2018.

Westoby, M. J., Brasington, J., Glasser, N. F., Hambrey, M. J. and Reynolds, M. J.: Structure-from-Motion photogrammetry: A low-cost, effective tool for geoscience applications, Geomorphology, 179, 300-314, 2012.

Xiang, J., Chen, J., Sofia, G., Yi, T., and Tarolli, P.: Open-pit mine geomorphic changes analysis using multi-temporal UAV survey, Environ. Earth. Sci., 77, 220, https://doi.org/10.1007/s12665018-7383-9, 2018. 